\author{
Marek Tracz-Tryniecki \\ University of Lodz, Poland \\ ORCID: 0000-0002-7622-8381 \\ cmppadt-mtt@wp.pl
}

\title{
The Principle of necessitas frangit legem in the Activity and Thought of Andrzej Maksymilian Fredro
}

\author{
Zasada necessitas frangit legem w działalności i myśli \\ Andrzeja Maksymiliana Fredry
}

\begin{abstract}
SUMMARY
The article presents the attitude of Andrzej Maksymilian Fredro - a key statesman and political writer in the $17^{\text {th }}$-century Polish-Lithuanian Commonwealth - toward the principle of necessitas frangit legem. At the beginning, the intellectual sources of his understanding of this principle are discussed. Two groups are referenced: one referring to the Christian legal view on necessitas and the other connected with the question of the reason of state. Then four aspects of Fredro's thought and political activity are analyzed. Firstly, his reference to necessitas treated as the justification of the amendment of the old law. Secondly, various examples of his flexible attitude toward law. All of them express Fredro's opinion on the key role of prudence in the process of applying law. Thirdly, the question of the infringement of law is discussed by referring to his concept of the exception from law and his reaction to Siciński's veto. Fourthly, it is pointed how in the context of the political conflict during the 1660s Fredro adopted a much stricter attitude toward observing the law. In the end, the conclusions state that Fredro's case is a good example of the dilemma of Polish political thought and practice of how to combine effective governance with the respect for constitutional forms.
\end{abstract}

Keywords: Andrzej Maksymilian Fredro; Polish-Lithuanian Commonwealth; necessitas frangit legem; law 


\section{SOURCES OF INSPIRATION}

Andrzej Maksymilian Fredro's approach toward the legal question, which constitutes an important area of his theoretical reflection and public activity, is detected by analyzing both his text as well as his political choices ${ }^{1}$. This article discusses Fredro's attitude toward the popular in the $17^{\text {th }}$-century Europe principle necessitas frangit legem ${ }^{2}$.

Trying to detect the sources that shaped the way of understanding the principle necessitas frangit legem and which most likely influenced Fredro, we could point to two groups: the first one is connected with the Christian reflection on law while the second one is related to the broad tradition of the reason of the state. In the literature on these topics, the origin of the discussed principle is connected with canon law, where in Gratian's Decretum was expressed in the form of legal maxim necessitas legem non habet ${ }^{3}$. It served to justify the departure from the pattern of behaviour complied with legal norm in the name of saving higher good. This approach was similar in meaning to the exception of the state of necessity. As Decretum was still in force as a part of Corpus Iuris Canonici this understanding of necessitas was still relevant and significant in Fredro's time.

We could take as quite probable the influence of St. Thomas Aquinas whose interpretation of Aristotle was dominant at the University in Kraków during Andrzej Maksymilian's studies ${ }^{4}$. Aquinas in his Summa Theologiae, in question 96, Article 6 discusses the problem: "Whether he who is under a law may act beside the letter of the law?"5. He claims that such behaviour is needed in the situation (casus), when the result of the action in accordance with the letter of the law would harm the common good, which constitutes the aim of the law. Although in the case that a person does not observe a letter of law, he or she follows the intention of the lawgiver (intentione legislatoris). Aquinas indicates that what must be taken into account is "the motive of the lawgiver (causam quae movit legislatorem), rather than of his very words" ${ }^{\text {" }}$. The assessment of what constitutes the good of a given community, and thus the decision to dispense from the letter

1 The overall analysis of Fredro's political and legal thought is presented in the monograph: M. Tracz-Tryniecki, Republika versus monarchia. Myśl polityczna i prawna Andrzeja Maksymiliana Fredry, Łódź 2019. This article constitutes partially a supplement to the previous researches.

2 See European Political Thought 1450-1700: Religion, Law and Philosophy, eds. H.A. Lloyd, G. Burgess, S. Hodson, New Heaven - London 2007, pp. 130, 224, 393-393, 448, 507.

3 See G. Agamben, State of Exception, Chicago 2008, pp. 24-25; J. Syryjczyk, Stan wyższej konieczności w prawie karnym kanonicznym, „Prawo Kanoniczne” 1982, no. 1-2, p. 282; W. Ostrożyński, Prawo wyższej konieczności, Lwów 1886, pp. 9-11.

4 See Z. Ogonowski, Filozofia szkolna w Polsce XVII wieku, Warszawa 1985, pp. 27-29.

5 St. Thomas Aquinas, Summa Theologiae. First Part of the Second Part, bilingual Latin and English edition, https://aquinas.cc/la/en/ ST.I-II.Q96.A5.Rep3 [access: 1.12.2020].

6 Ibidem. 
of law belongs to those who are in authority. But here St. Thomas provides for the following exception: "If, however, the peril be so sudden as not to allow of the delay involved by referring the matter to authority, the mere necessity brings with it a dispensation, since necessity knows no law (necessitas non subditur legi)"”. Necessitas therefore justifies the behaviour which on the one hand differs from the action demanded by the letter of the law, but on the other hand, results from the assessment of a given case and the recognition of what is a common good in these circumstances. Additionally, we could note that St. Paul also contrasts the letter and the Spirit of the law: "Who has indeed qualified us as ministers of a new covenant, not of letter but of spirit; for the letter brings death, but the Spirit gives life". As the influence of the Bible on Fredro's thought was predominant, the above-mentioned quote probably enables us to understand his generally negative approach to the letter of law.

The variety of concepts of the reason of the state was connected by referencing them to necessitas ${ }^{9}$. Although the notion of the reason of state was most completely discussed then by G. Botero, the important incentive for the development of this tradition, popular in the $16^{\text {th }}$ and $17^{\text {th }}$ centuries, was given by N. Machiavelli's works. In the context of the principle necessitas frangit legem we should note the Florentine's analysis concerning the Roman institution of dictatorship in Book I Chapter XXXIV of his Discourses on the First Ten Books of Titus Livius ${ }^{10}$. $\mathrm{He}$ is of the opinion that this institution is needed in a free government in case of urgent necessities. Otherwise: "For when a similar method is lacking in a Republic, either observing the institutions [strictly] will ruin her, or in order not to ruin her, it will be necessary to break them" ${ }^{11}$. Both of these consequences are assessed negatively by Machiavelli. Breaking the law is an extraordinary remedy that, while temporarily necessary, in the long-term sets a bad example for the citizens by accustoming them to disobeying the law. The Florentine concludes: "So that no Republic will be perfect, unless it has provided for everything with laws, and provided a remedy for every incident, and fixed the method of governing it"12. Thus, he proposes to introduce into a republican system the solutions, which, although contradictory to its core principles, will enable it to avoid breaking the law in an

${ }^{7}$ Ibidem.

82 Corinthians, 3, 6, https://bible.usccb.org/bible/2corinthians/3 [access: 30.11.2020].

9 See C. Zeron, Political Theories and Jesuit Politics, [in:] The Oxford Handbook of the Jesuits, ed. I.G. Županov, New York 2019, pp. 200-201.

${ }^{10}$ See the analysis of this part in: K. Prokop, Modele stanu nadzwyczajnego, Białystok 2012, pp. 65-68.

${ }^{11}$ N. Machiavelli, Discourses of Niccolo Machiavelli on the First Ten (Books) of Titus Livius, https://web.archive.org/web/20080220021325/http://ebooks.adelaide.edu.au/m/machiavelli/niccolo/ $\mathrm{m} 149 \mathrm{~d} / \mathrm{bk} 1 \mathrm{ch} 34 . \mathrm{html}$ [access: 7.09.2020].

12 Ibidem. 
emergency. However, we have no convincing evidence that Fredro had known this concept ${ }^{13}$.

There is no doubt that Andrzej Maksymilian encountered the maxim Necessitas omnem legem frangit in Lipsius' Politicorum, which he frequently recommended and quoted both in Latin and probably also in P. Szczerbic's Polish translation. The whole paragraph with the discussed quote reads as follow: Necessitas magnum imbecillitatis humanae patrocinium, omnem legem frangit ${ }^{14}$. Significantly, Lipsius notes that the maxim is taken from Seneca the Elder's Declamationum Excerpta, lib. 9. However, it refers only to the first part of the sentence, which is in italics in Politicorum: Necessitas magnum humanae imbecillitatis patrocinium est. We could not find in Seneca's work the part: Necessitas [...] omnem legem frangit ${ }^{15}$. Taking into account the enormous influence of Lipsius' Politicorum on the political elites of the Commonwealth and the rest of Europe, we could rightly assume that this work became the main source of knowing the discussed maxim at Fredro's time. Characteristically, in Western Europe the principle of necessitas omnem legem frangit was inter alia invoked by one of the main doctrinaires of French absolutism - Cardin Le Bret. He claims that various circumstances demand different attitudes towards the law, including breaking the edicts for the sake of the public good ${ }^{16}$. Thus, at that time the principle was known and functioned in Europe in different types of government, which obviously affected its various understandings.

\section{DEPARTURE FROM THE OLD LAW}

In the activity and thought of Fredro the reference to the principle necessitas frangit legem served mainly to justify the departure from the old law. Thus, it constituted de facto the key justification for legal change. We should note that the old

${ }^{13}$ On Fredro's knowledge of Machiavelli's Discourses see: M. Tracz-Tryniecki, Republika versus monarchia..., pp. 67-68.

14 J. Lipsius, Politica: Six Books of Politics or Political Instruction, transl. and ed. J. Waszink, Assen 2004, p. 530, lib. 4, cap. 14. The Polish translation: J. Lipsius, Politica panskie, to iest Navka iako pan y kazdy przelozony rzadnie zyć y sprawować sie ma: [...], transl. P. Sczerbic, Kraków 1595, p. 136.

15 Seneca Rhetor, Suasorice, Controversice, et Declamationum excerpta, Amstelodami 1619, p. 182. Lipsius, as an editor of Senecas' works, must have been aware of this fact.

${ }^{16}$ See C. Le Bret, De la Souveraineté du Roy, Paris 1632, p. 195; A Critical Dictionary of the French Revolution, eds. F. Furet, M. Ozouf, London 1989, p. 474. Considering that Le Bret, while referring to the discussed maxim, indicates Seneca's authorship, it can be assumed that he knew the principle from Lipsius' Politicorum. 
laws were highly respected in the Commonwealth ${ }^{17}$. Andrzej Maksymilian himself also appreciated them and was not eager to change them radically ${ }^{18}$.

Fredro encountered the principle of necessitas fragit legem in the public discourse at the beginning of his parliamentary career during the interregnum in 1648 . The context of the discussion was marked by the rapid progress of the Cossack rebellion and the state of interregnum. The problem whether the law should succumb to necessity was then widely discussed at the election sejm ${ }^{19}$. Fredro especially supported the opinion of A. Kisiel, a Kiev voivode, who justified the legality of the departure from the parliamentary procedures by referring to the noble citizens' will and the following principle:

Necessitas all in all fragit legem. Keeping the law, keeping formam Reipublicae, is a good thing, but in peacetime; currently by keeping the sejm's solennitates, and by denying this [the right to act contrary to the procedures - M.T.T.] during the sejm or after the sejm, and interim to be left without defence, to die by keeping formam Reipublicae, means to lose the Commonwealth ${ }^{20}$.

Andrzej Maksymilian shared this argument by claiming inter alia: "It seems novitas to some of you, that after the sejm we are considering the defence: but they do not perceive these novitates, which occurred due to the enemies" ${ }^{\prime 21}$. Thus, characteristically, Fredro connected here novitas with necessitas. In this context, it

${ }_{17}$ On the approach to the old law during the debate during the election sejm in 1648, see M. Tracz -Tryniecki, Wstep, [in:] A.M. Fredro, Gestorum Populi Poloni sub Henrico Valesio, Polonorum postea vero Galliae Rege / Dzieje Narodu Polskiego za czasów Henryka Walezego, Króla Polaków, potem zaś Francji, transl. J. Macjon, introduction and footnotes M. Tracz-Tryniecki, Warszawa 2018, pp. 92-93. The radical opinions during this discussion rejected any changes of the law, demanding only its more effective execution. This conservative approach to the old laws is clearly visible in the following quote: "We need nothing new, being content with the old law, which we do not give up" (J. Michałowski, Jakuba Michałowskiego, wojskiego lubelskiego a później kasztelana bieckiego, Księga pamiętnicza, transl. L. Morsztyn, Kraków 1864, p. 313).

${ }_{18}$ On the concept of the old law (leges antiquae) in Fredro's thought, see M. Tracz-Tryniecki, Republika versus monarchia..., pp. 281-285.

${ }_{19}$ On this discussion and the popularity of the opinion that the law should succumb to necessitas, see idem, Wstep..., pp. 91-92. The superiority of necessitas was directly mentioned, inter alia, by B. Leszczyński: "[...] necessitas of the dying homeland frangit legem, thus in must parere necessitati" (J. Michałowski, op. cit., p. 244), or H. Radziejowski: "[...] lex necessitati should succumb, alias I am afraid, that on legibus fundata civitas pereat, because in this way in Roman monarchy extremum libertatis initium servitutis, brought" (Diariusz sejmu elekcyjnego 1648 roku, ed. J.S. Dąbrowski, Kraków 2013, p. 89). J. Choińska-Mika (Zwycięstwo liberum veto na sejmach za Jana Kazimierza (1648-1668), „Biblioteka Epoki Nowożytnej. Liberum Veto” 2016, vol. 4(1), p. 52, 56) notes, that even earlier, under the King Vladislav IV, the members of parliament were ready to evade legal norms, including the parliamentary procedures, which constrained them. Similarly, at the time of disasters, local sejmiks had more elastic approach to the letter of law.

${ }_{20}$ J. Michałowski, op. cit., p. 355.

${ }^{21}$ Ibidem, p. 356. 
should be presumed that according to him necessitas are one of these new circumstances, which require a proper response - including a legal change.

Fredro's attitude toward legal change is clearly expressed in his parliamentary speech at the sejm in 1654, when he responded deputies, who claimed that old good laws could not be changed but only their proper execution is required. His approach was articulated in the statement that the change in circumstances requires new regulations: Novi casus requirunt novas leges ${ }^{22}$. What convinces us that this quote was not just an element of contemporary political struggle but his consistent opinion is the fact that he developed this idea later in his political writing: The Support of Liberty (Pol. Poparcie wolności) in 1668: "New cases bring new laws and acts" - there is an old Latin and Polish proverb. No legislator is so deeply provident to envisage and earlier safeguard all possible cases ${ }^{23}$.

We could therefore presume that these novi casus, or new cases are treated by Fredro as a justification for legal changes. This approach is in turn in accordance with A. Kisiel's opinion, which Andrzej Maksymilian had to have heard during the election sejm of 1648: casus faciunt leges ${ }^{24}$. One of the consequences of this conviction of the importance of a particular case for law-making is the necessity of discerning whether a given situation is so novel and unique, that it requires creating its specific pattern of the behaviour and thus to depart from the current regulations. It is therefore a kind of necessitas, which requires applying a virtue of prudence to discern and the virtue of justice to find a rule of action which is adequate to given circumstances.

Recognizing the soundness of changing the old law, Fredro indicates that it should be done by virtue of the will of the political nation. The will stays above the old law if the condition of neccessitas-novitas is fulfilled. Fredro especially stressed the supremacy of the national will in his speeches during the election sejm of 1648 and the coronation sejm of $1649^{25}$. Very characteristic is his statement made during the latter sejm, when he unsuccessfully defended himself from removal from the chamber of deputies during the procedure of rugi poselskie: "[...] in the situation when there is the law, the practice and custom withdraw. We have the law which

22 See S. Ochmann-Staniszewska, Z. Staniszewski, Sejm Rzeczypospolitej za panowania Jana Kazimierza Wazy. Praca - doktryna - polityka, Wrocław 2000, vol. 1, p. 194 and vol. 2, p. 41-42.

${ }^{23}$ A.M. Fredro, Poparcie wolności, [in:] Pisma polityczne z czasów panowania Jana Kazimierza Wazy 1648-1668, vol. 3: 1665-1668, ed. S. Ochmann-Staniszewska, Wrocław 1991, p. 317. During the researches in 2019, it was found that Fredro is the author of this writing, which up to that moment had been known as anonymous. This finding was based on a manuscript of the most complete version of this text at the Archiwum Prowincji Franciszkanów Reformatów in Kraków (no. 88, p. 115-128). This writing is currently being prepared for the publication.

${ }^{24}$ See Diariusz sejmu elekcyjnego..., p. 71; J. Michałowski, op. cit., p. 256.

${ }_{25}$ See Diariusz sejmu elekcyjnego..., pp. 47-48, 76, 87-88, 99-100, 143; J. Michałowski, op. cit., p. 272,302 . 
backs us up, because the whole Commonwealth, assembled during the election, agreed to hold a sejmik in Warsaw due to the fact that Wisznia was in danger"26.

Acknowledging the national right to adopt new laws and to change the old ones, Fredro cautions to not make this rapidly but moderately ${ }^{27}$.

The question of the self-reliance of the political nation during interregnum arose along with justifying the necessity of changing the old law. During the election sejm of 1648 two contradictory opinions, which recognized or denied the existence of this right, appeared ${ }^{28}$. Fredro definitely supported the latter. The nation during the period of interregnum is therefore entitled to make the decisions, which could departure from the existing legal order in order to adopt measures necessary to save the country ${ }^{29}$. At the verge of the next interregnum of 1668 , he came back to this concept presenting it with more doctrinally mature justification in the above-mentioned writing The Support of Liberty ${ }^{30}$. According to him, the political nation, which temporally regains its self-reliance during an interregnum, is also entitled to make deeper constitutional corrections by changing the fundamental laws (fundamentalne prawa) and formam Status. Furthermore, the change of these fundamentals of political regime is impermissible during the reign of a king. Thus, for Fredro interregnum is a kind of constitutional moment, when the political nation should respond to the needs arising from the current constitutional experience with legal changes. In this case, the recognition of necessitatem refers to the assessment of the whole period of the reign of the previous king ${ }^{31}$.

\section{FLEXIBLE APPROACH TO LAW}

The principle necessitas frangit legem could be also found in the other manifestations of Fredro's flexible approach to law. It especially refers to flexible interpretation of the law, which he preferred. Characteristically, in Gestorum there is a critique of too detailed provisions of the Henrician Articles comparing with

${ }^{26}$ S. Ochmann, Sejm koronacyjny Jana Kazimierza w 1649 r., Wrocław 1985, pp. 87-89.

27 See A.M. Fredro, Scriptorum Seu Togae et Belli Notationum Fragmenta. Accesserunt Peristromata Regum Symbolis expressa / Fragmenty pism, czyli uwagi o wojnie i pokoju. Zawieraja dodatkowo Emblematy Królów w Rycinach, Symbolicznie Odtworzone, transl. J. Chmielewska, B. Bednarek, introduction and footnotes M. Tracz-Tryniecki, Warszawa 2014, p. 543; idem, Vir Consilii Monitis Ethicorum nec non Prudentiae civilis. Praeludente apparatus Oratorii Copia ad Civiliter dicendum instructus, Leopoli 1730, pp. 516-518, 251.

${ }^{28}$ On the arguments of both groups, see M. Tracz-Tryniecki, Wstep ..., pp. 93-94.

29 Such extraordinary remedies were proposed by Fredro especially in 1648, during the rapid successes of Chmielnicki's rebellion. See Diariusz sejmu elekcyjnego..., pp. 87-88, 99-100, 143; J. Michałowski, op. cit., p. 272, 302.

${ }^{30}$ See A.M. Fredro, Poparcie wolności..., pp. 325-326.

${ }^{31}$ In the Commonwealth it had, inter alia, a form of notified grawamina. 
the previous regulations ${ }^{32}$. Fredro criticizes this solution, as it hinders flexible interpretation of the provisions and thus also flexible application of the law. Such a detailed approach in constitutional matters does not serve the question of freedom well. Perhaps the main source of this critique was the introduction of a six-week session for each sejm, which, together with the later provisions of the act of $1633^{33}$, seriously hindered prolongation of sejms and thus their effective legislative capacity. Indeed, these restrictions caused a lot of trouble with achieving consent during sejms, which in turn led to their ineffectiveness ${ }^{34}$. This context enables better understanding of Fredro's motives, when he presumed that the effectiveness of republican institutions is a condition for the existence of political freedom.

It is also worthy to draw attention to the writing "Contraventio legibus quibus armatur et utuntur Poloni $\mathrm{w}$ izbie poselskiej na ścianie przylepione i znalezione" (which was found stuck on the wall of the chamber of deputies). Probably, Fredro was the author of this anonymous piece of work, which appeared during the sejm in winter $1652^{35}$. It contained a sharp satire which mocked the casuistic and formalistic approach of the Poles to the law:

They keep the law, without which not only publica, but also private geruntur negotia, and even sine lege they do not take their seats, or do not let the way to one each others - until they kill each others. [...] Why do they follow the law, but despise [the law] of God? [...] A Pole goes to a church - in spite of officium he is equipped with the statutes, which he opens during the Mass and looks at them; in spite of "Our Father..." - he reads the law to God, he is said to want to remain under the law. [...] And because absque lege nothing could happen during the current sejm, he [a Pole] wishes you [the deputies] to adopt novam legem: which regulates where a nobleman will go after death: to Heaven or hell? ${ }^{36}$

The Poles are therefore blamed that in stiffly keeping the letter of the law, they are deaf to the law of God with its equity. Consequently, such approach makes effective actions impossible, including resolving public problems. Indeed, the writing concerns the phenomenon of increasing legal rigor and formalism among deputies at that time, which is assessed as destructive to the functioning of the parliamentary system of the Commonwealth ${ }^{37}$. However, it must also be noted that

32 See A.M. Fredro, Gestorum..., pp. 515-517. In the other works Fredro argues that the newly created legal provisions must be clear in their meaning. See idem, Vir consilii..., p. 347.

33 Volumina Legum, vol. 3, Petersburg 1859, p. 373.

${ }^{34}$ See H. Olszewski, Sejm Rzeczypospolitej epoki oligarchii 1652-1763. Prawo - praktykateoria - programy, Poznań 1966, p. 316; E. Opaliński, Liberum veto, „Przegląd Polityczny” 2007, no. 81, p. 83; J. Choińska-Mika, op. cit., p. 51, 54.

${ }_{35}$ On the possible authorship of Fredro, see M. Tracz-Tryniecki, Wstęp ..., pp. 63-64.

${ }^{36}$ Contraventio legibus armatur et utuntur Poloni, [in:] Pisma polityczne z czasów panowania Jana Kazimierza Wazy 1648-1668, vol. 1: 1648-1660, ed. S. Ochmann-Staniszewska, Wrocław 1989, pp. 97-98.

${ }^{37}$ See J. Choińska-Mika, op. cit., p. 68. 
one of the aims of Contraventio legibus was to justify the procedural infringements committed during the political trial of $\mathrm{H}$. Radziejowski, a deputy chancellor of the Crown, by referring to the necessity of the existence of an effective royal power.

Said flexibility is also visible in Fredro's approach to the instructions given by sejmiks to their deputies (instrukcje sejmikowe). During the sejm of 1654, he argued that the strict adherence to the instructions would make it impossible to reach consensus. By presenting the proper model of the relation between a deputy and his sejmik, he states as follows: "Those who blindly keep their instructions do not know why they are in sejm. In the past, deputies did not receive written instruction, but fides, virtus, dexteritas, prudential were their viaticum. According to them, they settled everything during sejms" ${ }^{\prime 38}$.

Similarly, in the project of reform created at the end of "the deluge" (the Northern War of 1655-1660), titled: "A consideration necessary for quick and effective conclusions of sejms" (Pol. "Uważenie potrzebne do prędkiego zawierania sejmów"), which Fredro was most likely one of the authors of, there was a postulate to not reveal the matters of a forthcoming $\operatorname{sejm}^{39}$. It would preclude sejmiks to give instructions, which hinder free deliberations "according to conscience and for the public good" and "to conclude what expedit" ${ }^{40}$. It could be therefore clearly noticed that for Andrzej Maksymilian the deputies should first of all base their decisions on virtue - especially on prudence. This enables them in turn to recognize the common good according to a given situation and adopt adequate and just measures. The instructions become obstacles to this way of action ${ }^{41}$.

Fredro's above-described flexible approach to the law, which manifests in the concepts of legal change and legal interpretation in his critique of both formalism and, indirectly, of the strict binding force of the instructions for deputies, have all one common denominator. This is the reference to the virtue of prudence combined with the orientation toward the aim of law, which is the common good. According to Andrzej Maksymilian, the law should first of all provide principles, which would be specified in details during their application depending on the need of a given situation. This leaves room for prudence, which should recognize which solution

${ }^{38}$ S. Ochmann-Staniszewska, Z. Staniszewski, op. cit., vol. 1, p. 195 and vol. 2, p. 39.

39 On the probable authorship of Fredro, see M. Tracz-Tryniecki, Republika versus monarchia..., p. 33 .

${ }^{40}$ See Uważenie potrzebne do prędkiego zawierania sejmów, [in:] Pisma polityczne..., vol. 1, p. 235 .

${ }^{41}$ It is worth to note, that a king was especially interested in lack binding force of the instruction. The researchers usually pay attention on generally lax attitude of deputies toward their instructions in the first period of the reign of King John II Casimir Vasa. The departure from the instruction was usually explained by the common consent. See E. Opaliński, Sejm srebrnego wieku 1587-1652. Między głosowaniem większościowym a liberum veto, Warszawa 2001, pp. 159-160. 
would be a proper actualization of a principle in particular conditions ${ }^{42}$. This requires paying special attention to the goal of a given institution and the intentions that the legislator had during its enactment (intentionem legislatoris) ${ }^{43}$. This mode of reasoning is especially visible in the way Fredro refers to precedents ${ }^{44}$. He carefully analyzes history to find precedents' patterns and the reasons behind them. In this way, he aims to understand the motives (rationes) of those who created the norms ${ }^{45}$. He clearly describes this in the following quote: Res vero omnes, magis debent fieri a ratione, quam ab exemplo, imo exemplum, fundari debet super ratione, non ratio super exemplo ${ }^{46}$.

\section{THE INFRINGEMENT OF THE RULE}

Similar argumentation was used in the concept of exception to the law (exceptionem legis), which was discussed by Fredro ${ }^{47}$. The construct of the exception is based on the premise of the rationality of a legislator, who pursues that which is beneficial and useful for the common good (utilitate communis boni). Hence, the different results of legal interpretation must be rejected as absurd. Andrzej Maksymilian is convinced that the general nature of the law does not make it possible to predict all possible future cases. The exception to the law therefore constitutes a solution, which is essentially put in the legal system. Thanks to the virtue of prudence it enables the elimination of legal interpretations, which results in situations contradictory to the aim of the law. By basing the exception to the law on prudence and the aim of the law, which should also be the intention of a legislator, Fredro clearly refers to St. Thomas Aquinas. It is worth noting that Aquinas also refers to necessity when he discusses the principle of the exception to the law.

Fredro's reference to necessitas in the context of W. Siciński's veto during the winter sejm of 1652 had another nature. As a chairman of the chamber of deputies (marszatek izby poselskiej), he attempted to prevent the sejm from recognizing the validity of the protest of Siciński, a deputy from Upita ${ }^{48}$. In his dramatic address

${ }^{42}$ See M. Tracz-Tryniecki, Wstęp..., pp. 218-219.

${ }^{43}$ See A.M. Fredro, Vir Consilii..., pp. 295-296; idem, Gestorum ..., pp. 273-274.

44 The whole concept of Gestorum constitutes de facto a reference to precedent - the constitutional moment of the Commonwealth during the Great Interregnums of the $16^{\text {th }}$ century. See M. Tracz-Tryniecki, Wstęp ..., pp. 25, 125-126, 211, 256-257. Fredro also in his parliamentary activity used the arguments, which referred to the previous precedents. See W. Czapliński, Dwa sejmy roku 1652, Wrocław 1955, p. 101.

45 See A.M. Fredro, Gestorum ..., p. 19, 94.

46 Idem, Vir Consilii..., p. 287.

${ }^{47}$ See ibidem, p. 296.

${ }^{48}$ Fredro's attitude toward Siciński's veto is broadly discussed in: M. Tracz-Tryniecki, Andrzej Maksymilian Fredro na sejmie zwyczajnym 1652 r. - nowe spojrzenie, [in:] Na sejmikach i sejmach. 
toward both united chambers in the evening on March 9, 1652, he stressed that as the consequence of the recognition of the veto the Motherland would be exposed to the greatest threat ${ }^{49}$. By doing this he acted and tried to persuade the members of the sejm to behave contrary to the principle which demanded respecting an individual protest. It must be noted that the opinion on the existence of this principle, which was a logical but radical consequence of unanimous consensus (unanimus consensus $)^{50}$, had already been present in the public debate of the first half of the $17^{\text {th }}$ century ${ }^{51}$. Moreover, at the winter sejm in 1652 the conviction about the binding force of this principle was expressed inter alia by the leading politicians of the royal party $^{52}$. However, Fredro rejected this rigid legalistic interpretation of unanimity and he followed the pragmatic concern for the good of the Commonwealth. The latter justified even non-application of the law which put her in danger. Hence, in the case of Sicinski's veto, Fredro attempted in the name of the necessity of saving the country to prevent the precedential use of the principle, which was deeply rooted in the debate and found logically, based on the existing political regime.

\section{A CHANGE IN FREDRO'S APPROACH}

Fredro's above-described approach to the law and the principle of necessitas partially changed during the period of the political struggles over the royal project of the election vivente rege. He was in opposition to the king at that time. The change in Andrzej Maksymilian's approach referred to the questions of the immutability of the old laws, the respect for the instructions given to deputies, the recognition

Szlachta ziemi przemyskiej w życiu politycznym Rzeczypospolitej XVI-XVIII wieku, ed. D. Kupisz (in print).

49 See Recessus actorum comitialium in Anno 1652 Mense Januario, [in:] Akta miasta GdańskaRecesy Stanów Prus Królewskich, Archiwum Państwowe w Gdańsku, sygn. APG: 300,29/136, k. 171r. See also: W. Czapliński, Dwa sejmy..., p. 122 and partially A. Kersten, Hieronim Radziejowski. Studium władzy i opozycji, Warszawa 1988, p. 308. It is worth to note that also earlier the necessity "to save the Motherland" served as a justification for the infringements of the law in the sejms, especially of parliamentary procedures. See S. Ochmann-Staniszewska, Z. Staniszewski, op. cit., vol. 2, pp. 225-226.

${ }^{50}$ Later, in 1668, Fredro himself identified ius vetandi with the principle of the unanimous (or more literally "one common") consent (zgoda jednopowszechna). See A.M. Fredro, Poparcie wolności..., p. 319.

${ }^{51}$ In the debate there were both opinions: which supported pluralista votorum, and which recognized the binding force of a single deputy's protest. See E. Opaliński, Sejm..., pp. 161-162; J. Choińska-Mika, op. cit., p. 52.

${ }^{52}$ See especially the statement of D. Żytkiewicz of February 20, 1652. On March 11, 1652, after Siciński's veto, this principle was explicite recognized by, inter alia, a deputy chancellor of the Crown (podkanclerzy koronny) S. Koryciński or a chancellor of Lithuania (kanclerz litewski) A.S. Radziwiłł. See W. Czapliński, Dwa sejmy..., p. 100; Recessus actorum comitialium ..., k. 172v. 
of liberum veto, the application of the article de non praestanda oboedientia, and the assessment of Radziejowski's case ${ }^{53}$.

During the parliamentary struggles at the 1661 sejm, Fredro fiercely opposed, initially alone, any changes in the old laws: "I do prefer to stand up for the old laws, and I prefer to rather go astray without violating them, than to be wise by trampling them" ${ }^{54}$. He expressed the unwilling attitude toward the change of the old laws in his Scriptorum, published a year earlier ${ }^{55}$. Certainly, his main motive was the fact that in the Commonwealth the old laws were the basis of noblemen's liberties ${ }^{56}$. While the proposed royal reforms intended to introduce an election during a reign of a king and changes in the mode of parliamentary procedures, which would practically limit citizen participation in the government, and would have certainly shrunk the scope of political freedoms ${ }^{57}$. The bond between freedom and the old laws is well-expressed in the advice, which Fredro gave to his sons: "At the sejms do not propose any changes, watch over the old laws and liberties, because the new ones will rather do more harm than improve" 58 . However, it must be noted that even in this approach the restraint from the changes of the old laws refers to the sejms during the reign of a king at the Commonwealth ${ }^{59}$. At the time of interregnum, as mentioned above, the political nation regains the ability to make fundamental legal changes ${ }^{60}$.

In the 1660s, Fredro unequivocally criticised the violations of law in the trial of Radziejowski. In his above-mentioned writing The Support of Liberty of 1668, he named the cases of both the former deputy chancellor and the later one of J.S. Lubomirski as examples of effective "entrapment" of freedom by the king ${ }^{61}$.

${ }^{53}$ The common character of this change was observed by the authors of the monograph of the sejms under King John Casimir: "This relatively lax earlier attitude toward the old and new laws changed during the sixties as the reaction to the strongly supported project of the election vivente rege of a French candidate. The nobility began to perceive threats even in every change of the old law, not to mention the introduction of the new one" (S. Ochmann-Staniszewska, Z. Staniszewski, op. cit., vol. 2, p. 42).

${ }^{54}$ W. Kochowski, Historya panowania Jana Kazimierza z Klimakterów Wepazyana Kochowskiego, vol. 2, Poznań 1840, p. 120.

${ }_{55}$ See A.M. Fredro, Scriptorum ..., p. 543, 547.

56 See D. Malec, The nobility's privileges and the formation of civil liberties in old Poland, [in:] Magna Carta: A Central European Perspective of Our Common Heritage of Freedom, eds. Z. Rau, P. Żurawski vel Grajewski, M. Tracz-Tryniecki, London - New York 2016, pp. 127-146.

57 See, i.a., the radical plan of reforms described by W. Czapliński (Próby reform państwa w czasie najazdu szwedzkiego, [in:] Polska w okresie drugiej wojny pótnocnej 1655-1660, ed. A. Przyboś, vol. 1, Warszawa 1957, p. 325).

${ }_{58}$ A.M. Fredro, Ojcowskie synom przestrogi, [in:] Ojcowskie synom przestrogi. Instrukcje rodzicielskie (XVI-XVII w.), eds. D. Żołądź-Strzelczyk, M. Kowalczyk, Wrocław 2017, p. 388.

${ }^{59}$ See idem, Poparcie wolności ..., pp. 323, 325-326.

${ }^{60}$ See ibidem, pp. 325-326.

${ }^{61}$ See ibidem, p. 317, 327. 
The experiences of both these trials prompted Fredro to formulate the postulate of a much more consistent separation of judicial power from the king, which was accompanied by a proposal to extend the jurisdiction of the Crown Tribunal ${ }^{62}$. This, in turn, led him to construct the justification of the division of power that was close to what was later created by Montesquieu.

In the discussed period we also see the change in Fredro's approach toward the question of the infringement of the law by a king as the basis for the application of the article de non praestanda oboedientia. Although he always stressed the need of the law to be observed by those who govern, in Gestorum of 1652 he presented a forgiving attitude toward the errors of a king, especially toward unintentional infringements of norms ${ }^{63}$. Fredro also emphasized that disobeying procedure must be preceded by warnings given by a senate to a king. However, in Scriptorum published in 1660 his approach to this issue was much more rigorous: "If he [a king] breaks or neglects any provision, he would lose the name of a king and become a tyrant to the law and the people, and a real liar" $" 64$.

As the instructions for the deputies are concerned, the change of Fredro's approach is expressed in his support for strict adherence to them. In order to discipline deputies, he proposed that the assessment of their activity by sejmiks should be combined with the possibility of sejmiks deciding the penalty for the deputies who departure from their instructions. He argued in the following way: "The penalty on the wicked is needed, because without it much evil has been seen to be done contrary to the interdictions of the brother-citizens, and a reprimand alone without the punishment in a broken world and among a spoiled people could only help a little" ${ }^{65}$. Similarly, from the 1660 s, Fredro expressed a different attitude to the liberum veto than in $1652^{66}$. He began to defend the soundness of the institution of an individual contradiction, although he provided some serious restrictions of its

${ }^{62}$ Ibidem, p. 327. He expressed this view in his speech at the $2^{\text {nd }}$ Sejm of 1666 , when he postulated to transfer the jurisdiction of carmen lease maiestatis from a king to the Tribunal. See idem, Votum Seymowe, A.D. 1666. Post bellum Civile, [in:] F. Glinka, Zwierzyniec Iednorozcow. Z Przydatkiem Rożnych Mow, Seymowych, Listow, Pism y Dyskusow, tak Polskich, iako y Łacińskich, Lwów 1670, p. 193. The postulate of extending the scope of the Tribunal's jurisdiction, which was expressed in The Support of Liberty, was notice by W. Bodnaruk, although without identifying its author. See W. Bodnaruk, Trybunat Koronny. Szlachecki sąd najwyższy w latach 1578-1794, Lublin 2008, pp. 88-89.

${ }^{63}$ See A.M. Fredro, Gestorum ..., p. 467, 517; M. Tracz-Tryniecki, Wstęp ..., pp. 223-224.

${ }_{64}$ A.M. Fredro, Scriptorum ..., p. 205.

${ }^{65}$ Idem, Poparcie wolności..., p. 324.

${ }^{66}$ See idem, Scriptorum ..., pp. 436-451, 540-541; idem, Epistola ad Amicum, Zamość 1669 (pages without pagination, printed pages no. 14-16); idem, Vir Consilii..., pp. 551-552. The change of Fredro's attitude toward the law was characteristic to the nobility at the time of the disputes over the royal project of the election vivente rege. See S. Ochmann-Staniszewska, Z. Staniszewski, op. cit., vol. 2, pp. 41-44; A. Król, Sejmik ziem lwowskiej, przemyskiej i sanockiej w Sądowej Wiszni za panowania Wazów (1587-1668), Przemyśl 2018, p. 167. 
use $^{67}$. In the context of political disputes with the royal court both - maintaining the strict control of the political nation over its deputies and rigid observation of the laws constituting the constitutional guarantees, including ius vetandi-were to provide effective tools against the strength of royal power. Especially that during these struggles the king unfortunately used methods such as bribery, blackmail or threats ${ }^{68}$. The aim of this dispute was to maintain the free republican form of government and to protect the Commonwealth from imposing external dependency on Her in the person of a foreign candidate for the throne.

To close the analysis presented above of the change in Fredro's approach it must be noted that later, during the period of the two next native kings, he again expressed a more flexible attitude toward the law. A few times he proposed major changes in the functioning of the state ${ }^{69}$. What remained unchanged in Fredro's view was his sensitivity to the observation of laws guaranteeing free political government, including his emphasis on the division of power.

\section{CONCLUSIONS}

The principle necessitas frangit legem in Fredro's thought primarily served to leave room for the virtue of prudence in the process of applying the law. This virtue demands to recognize what constitutes the common good in a given situation thus, to look at the proper aim of the law. According to Fredro, due to the inherent natural limitations of the statutory law, prudence enables appropriate actions in unusual situations. Prudence enables an elastic approach to the law - to its change, interpretation or deviation from its norms in situations where obeying them would lead to a disaster. This also considers a laxer attitude toward the instructions given to the deputies. Fredro's approach was motivated both by the responsibility for the state, which revealed the influence of the reason of state concept, and by the awareness that preserving freedom demands an efficient state operation. During the political struggles over the project of the election vivente rege, we notice the change in Andrzej Maksymilian's attitude. The hardening of his approach to the law intended to strengthen the power of the institutional guarantees that preserve free government. This more legalistic approach to the law also resulted in greater

${ }^{67}$ See M. Tracz-Tryniecki, Wstęp ..., pp. 35-39; Z. Ogonowski, Nad pismami Fredry. Wobronie liberum veto, cz. 2, „Człowiek i Światopogląd” 1975, no. 5, pp. 100-103; S. Ochmann, Sejmy lat 1661-1662. Przegrana batalia o reformę ustroju Rzeczypospolitej, Wrocław 1977, p. 31.

${ }^{68}$ The dissemination of the opinion about the need to respect individual protests and the sejmiks' instructions in the 1960s was noticed by J. Choińska-Mika (op. cit., p. 54).

${ }^{69}$ His most important proposed changes referred to the introduction of tenure of office of the crucial offices in place of their lifelong holding and the election of a native king. See A.M. Fredro's Epistola ad Amicum and the later Vir Consilii. 
constitutional sensitiveness and prompted Fredro to formulate a mature vision of the division of power.

Fredro's case is a good example of the dilemmas of both political and legal thought and practice in the Polish-Lithuanian Commonwealth ${ }^{70}$. They are even more obvious when we compare them with the situation in Western Europe, which is well expressed by M. Viroli's description of Italy in the $16^{\text {th }}$ century:

As structural changes in political order undermined the authority of medieval practices of "mixed constitutionalism", scholars oriented their inquiries away from questions about the origins and legitimacy of government and towards effective methods with which rulers might maintain and enhance the power of the state. Instead of focusing on constitutional forms, these new studies addressed the art of governing ${ }^{71}$.

Andrzej Maksymilian attempted to reconcile these two problems in his works and actions. The prevalence of one of them in his reflection was determined by practical context of the Commonwealth political situation. At the same time, a decisive role in keeping the balance between them was played by his approach to the principle necessitas frangit legem.

\section{REFERENCES}

2 Corinthians, 3, 6, https://bible.usccb.org/bible/2corinthians/3 [access: 30.11.2020].

A Critical Dictionary of the French Revolution, eds. F. Furet, M. Ozouf, London 1989.

Agamben G., State of Exception, Chicago 2008.

Bodnaruk W., Trybunat Koronny. Szlachecki sąd najwyższy w latach 1578-1794, Lublin 2008.

Choińska-Mika J., Zwycięstwo liberum veto na sejmach za Jana Kazimierza (1648-1668), „Biblioteka

Epoki Nowożytnej. Liberum Veto" 2016, vol. 4(1).

Contraventio legibus armatur et utuntur Poloni, [in:] Pisma polityczne z czasów panowania Jana

Kazimierza Wazy 1648-1668, vol. 1: 1648-1660, ed. S. Ochmann-Staniszewska, Wrocław 1989.

Czapliński W., Dwa sejmy roku 1652, Wrocław 1955.

Czapliński W., Próby reform państwa w czasie najazdu szwedzkiego, [in:] Polska w okresie drugiej wojny pótnocnej 1655-1660, ed. A. Przyboś, vol. 1, Warszawa 1957.

Diariusz sejmu elekcyjnego 1648 roku, ed. J.S. Dąbrowski, Kraków 2013.

European Political Thought 1450-1700: Religion, Law and Philosophy, eds. H.A. Lloyd, G. Burgess, S. Hodson, New Heaven - London 2007.

${ }^{70}$ J. Choińska-Mika (op. cit., p. 52) rightly notes that "the essence was the conflict between legalism and pragmatism". In this context, we should remain more sceptic to K. Friedrich's opinion that the principle necessitas non habet legem was not adopted in the Commonwealth. See K. Friedrich, Poland-Lithuanian, [in:] European Political Thought..., p. 224. Based on Fredro's example, it can be stated that this principle was, depending on the situation, an approved argument in the contemporary political discussion.

${ }^{71}$ M. Loughlin, Political Jurisprudence, Oxford - New York 2017, p. 144. 
Friedrich E., Poland-Lithuanian, [in:] European Political Thought 1450-1700: Religion, Law and Philosophy, eds. H.A. Lloyd, G. Burgess, S. Hodson, New Heaven - London 2007.

Fredro A.M., Epistola ad Amicum, Zamość 1669.

Fredro A.M., Gestorum Populi Poloni sub Henrico Valesio, Polonorum postea vero Galliae Rege I Dzieje Narodu Polskiego za czasów Henryka Walezego, Króla Polaków, potem zaś Francji, transl. J. Macjon, introduction and footnotes M. Tracz-Tryniecki, Warszawa 2018.

Fredro A.M., Ojcowskie synom przestrogi, [in:] Ojcowskie synom przestrogi. Instrukcje rodzicielskie (XVI-XVII w.), eds. D. Żołądź-Strzelczyk, M. Kowalczyk, Wrocław 2017.

Fredro A.M., Poparcie wolności, [in:] Pisma polityczne z czasów panowania Jana Kazimierza Wazy 1648-1668, vol. 3: 1665-1668, ed. S. Ochmann-Staniszewska, Wrocław 1991.

Fredro A.M., Scriptorum Seu Togae et Belli Notationum Fragmenta. Accesserunt Peristromata Regum Symbolis expressa / Fragmenty pism, czyli uwagi o wojnie i pokoju. Zawieraja dodatkowo Emblematy Królów w Rycinach, Symbolicznie Odtworzone, transl. J. Chmielewska, B. Bednarek, introduction and footnotes M. Tracz-Tryniecki, Warszawa 2014.

Fredro A.M., Vir Consilii Monitis Ethicorum nec non Prudentiae civilis. Praeludente apparatus Oratorii Copia ad Civiliter dicendum instructus, Leopoli 1730.

Fredro A.M., Votum Seymowe, A.D. 1666. Post bellum Civile, [in:] F. Glinka, Zwierzyniec Iednorozcow. Z Przydatkiem Rożnych Mow, Seymowych, Listow, Pism y Dyskusow, tak Polskich, iako y Eacińskich, Lwów 1670.

Kersten A., Hieronim Radziejowski. Studium władzy i opozycji, Warszawa 1988.

Kochowski W., Historya panowania Jana Kazimierza z Klimakterów Wepazyana Kochowskiego, vol. 2, Poznań 1840.

Król A., Sejmik ziem lwowskiej, przemyskiej i sanockiej w Sądowej Wiszni za panowania Wazów (1587-1668), Przemyśl 2018.

Le Bret C., De la Souveraineté du Roy, Paris 1632.

Lipsius J., Politica panskie, to iest Navka iako pan y kazdy przelozony rządnie zyć y sprawować sie ma: [...], transl. P. Sczerbic, Kraków 1595.

Lipsius J., Politica: Six Books of Politics or Political Instruction, transl. and ed. J. Waszink, Assen 2004.

Loughlin M., Political Jurisprudence, Oxford - New York 2017.

Machiavelli N., Discourses of Niccolo Machiavelli on the First Ten (Books) of Titus Livius, https:// web.archive.org/web/20080220021325/http://ebooks.adelaide.edu.au/m/machiavelli/niccolo/ $\mathrm{m} 149 \mathrm{~d} / \mathrm{bk} 1 \mathrm{ch} 34 . \mathrm{html}$ [access: 7.09.2020].

Malec D., The nobility's privileges and the formation of civil liberties in old Poland, [in:] Magna Carta: A Central European Perspective of Our Common Heritage of Freedom, eds. Z. Rau, P. Żurawski vel Grajewski, M. Tracz-Tryniecki, London - New York 2016.

Michałowski J., Jakuba Michałowskiego, wojskiego lubelskiego a później kasztelana bieckiego, Księga pamiętnicza, transl. L. Morsztyn, Kraków 1864.

Ochmann S., Sejm koronacyjny Jana Kazimierza w 1649 r., Wrocław 1985.

Ochmann S., Sejmy lat 1661-1662. Przegrana batalia o reformę ustroju Rzeczypospolitej, Wrocław 1977.

Ochmann-Staniszewska S., Staniszewski Z., Sejm Rzeczypospolitej za panowania Jana Kazimierza Wazy. Praca-doktryna - polityka, vol. 1-2, Wrocław 2000.

Ogonowski Z., Filozofia szkolna w Polsce XVII wieku, Warszawa 1985.

Ogonowski Z., Nad pismami Fredry. W obronie liberum veto, cz. 2, „Człowiek i Światopogląd” 1975, no. 5.

Olszewski H., Sejm Rzeczypospolitej epoki oligarchii 1652-1763. Prawo-praktyka-teoria - programy, Poznań 1966.

Opaliński E., Liberum veto, „Przegląd Polityczny” 2007, no. 81. 
Opaliński E., Sejm srebrnego wieku 1587-1652. Między głosowaniem większościowym a liberum veto, Warszawa 2001.

Ostrożyński W., Prawo wyższej konieczności, Lwów 1886.

Prokop K., Modele stanu nadzwyczajnego, Białystok 2012.

Recessus actorum comitialium in Anno 1652 Mense Januario, [in:] Akta miasta Gdańska-Recesy Stanów Prus Królewskich, Archiwum Państwowe w Gdańsku, sygn. APG: 300,29/136.

Seneca Rhetor, Suasorice, Controversice, et Declamationum excerpta, Amstelodami 1619.

St. Thomas Aquinas, Summa Theologiae. First Part of the Second Part, bilingual Latin and English edition, https://aquinas.cc/la/en/ ST.I-II.Q96.A5.Rep3 [access: 1.12.2020].

Syryjczyk J., Stan wyższej konieczności w prawie karnym kanonicznym, „Prawo Kanoniczne” 1982, no. $1-2$.

Tracz-Tryniecki M., Andrzej Maksymilian Fredro na sejmie zwyczajnym 1652 r. - nowe spojrzenie, [in:] Na sejmikach i sejmach. Szlachta ziemi przemyskiej w życiu politycznym Rzeczypospolitej XVI-XVIII wieku, ed. D. Kupisz (in print).

Tracz-Tryniecki M., Republika versus monarchia. Myśl polityczna i prawna Andrzeja Maksymiliana Fredry, Łódź 2019.

Tracz-Tryniecki M., Wstęp, [in:] A.M. Fredro, Gestorum Populi Poloni sub Henrico Valesio, Polonorum postea vero Galliae Rege / Dzieje Narodu Polskiego za czasów Henryka Walezego, Króla Polaków, potem zaś Francji, transl. J. Macjon, introduction and footnotes M. Tracz-Tryniecki, Warszawa 2018.

Uważenie potrzebne do prędkiego zawierania sejmów, [in:] Pisma polityczne z czasów panowania Jana Kazimierza Wazy 1648-1668, vol. 1: 1648-1660, ed. S. Ochmann-Staniszewska, Wrocław 1989.

Volumina Legum, vol. 3, Petersburg 1859.

Zeron C., Political Theories and Jesuit Politics, [in:] The Oxford Handbook of the Jesuits, ed. I.G. Županov, New York 2019.

\section{STRESZCZENIE}

Niniejszy artykuł dotyczy stosunku Andrzeja Maksymiliana Fredry, jednego z kluczowych mężów stanu i pisarzy politycznych siedemnastowiecznej Rzeczypospolitej Obojga Narodów, do zasady necessitas frangit legem. Na początku omówiono źródła intelektualne kształtujące jego rozumienie tej zasady. Wskazano na dwie grupy: związaną ze spojrzeniem chrześcijańskiej myśli prawniczej na necessitas oraz odnoszącą się do kwestii racji stanu. Analizie poddano cztery aspekty myśli i działalności Fredry. Po pierwsze, wskazano na odwołanie do necessitas jako uzasadnienia zmiany starego prawa. Po drugie, przedstawiono różne przykłady elastycznego podejścia do prawa, wyrażające opinię Fredry o kluczowej roli roztropności w procesie stosowania prawa. Po trzecie, omówiono problem naruszenia prawa, odnosząc go do Fredrowskiej koncepcji wyjątku od prawa oraz do jego reakcji na weto Sicińskiego. Po czwarte, wskazano, jak Fredro - w kontekście konfliktu politycznego lat 60. XVII w. - przyjął znacznie bardziej sztywne stanowisko wobec przestrzegania prawa. W konkluzjach stwierdzono, że przypadek Fredry stanowi dobry przykład dylematów dotyczących sposobu połączenia skutecznego rządzenia z poszanowaniem form konstytucyjno-ustrojowych, przed jakim stanęła zarówno myśl polityczna, jak i praktyka Rzeczypospolitej.

Slowa kluczowe: Andrzej Maksymilian Fredro; Rzeczpospolita Obojga Narodów; necessitas frangit legem; prawo 